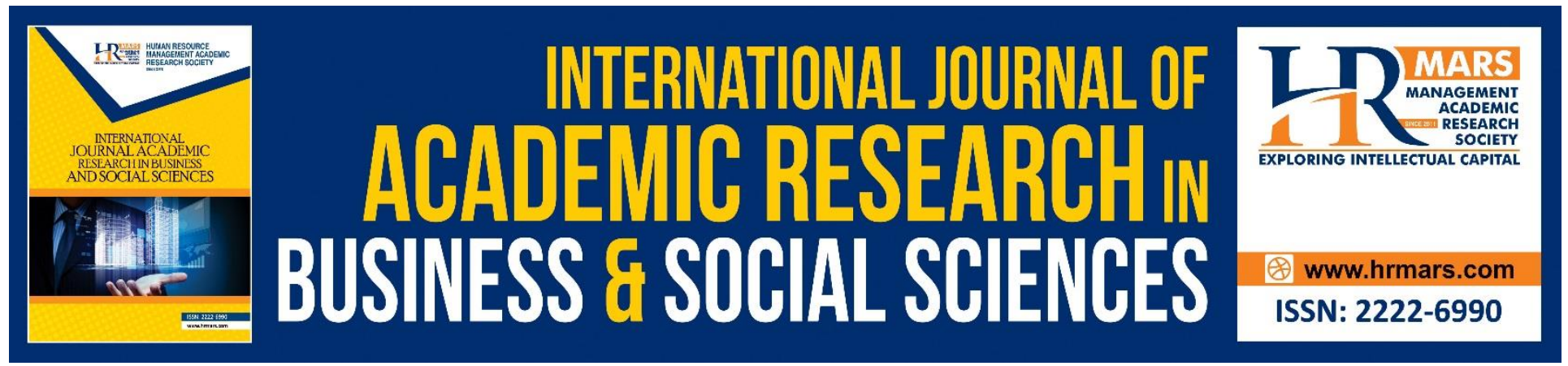

\title{
Impacts of Rewards, Promotions and Supervisor Support on Academic Staff's Performance: An Empirical Study in Malaysian Universities
}

Safiah Rashid, Mohamed Faroug Ben Hamza, Haliza Mohd Said

To Link this Article: http://dx.doi.org/10.6007/IJARBSS/v8-i9/4877

DOI: $10.6007 /$ IJARBSS/v8-i9/4877

Received: 06 August 2018, Revised: 27 August 2018, Accepted: 17 Sept 2018

Published Online: 28 Sept 2018

In-Text Citation: (Rashid, Hamza, \& Said, 2018)

To Cite this Article: Rashid, S., Hamza, M. F. Ben, \& Said, H. M. (2018). Impacts of Rewards, Promotions and Supervisor Support on Academic Staff's Performance: An Empirical Study in Malaysian Universities.

International Journal of Academic Research in Business and Social Sciences, 8(9), 1983-1998.

Copyright: (c) 2018 The Author(s)

Published by Human Resource Management Academic Research Society (www.hrmars.com)

This article is published under the Creative Commons Attribution (CC BY 4.0) license. Anyone may reproduce, distribute, translate and create derivative works of this article (for both commercial and non-commercial purposes), subject to full attribution to the original publication and authors. The full terms of this license may be seen at: http://creativecommons.org/licences/by/4.0/legalcode

Vol. 8, No. 9, September 2018, Pg. 1983 - 1998

Full Terms \& Conditions of access and use can be found at http://hrmars.com/index.php/pages/detail/publication-ethics 


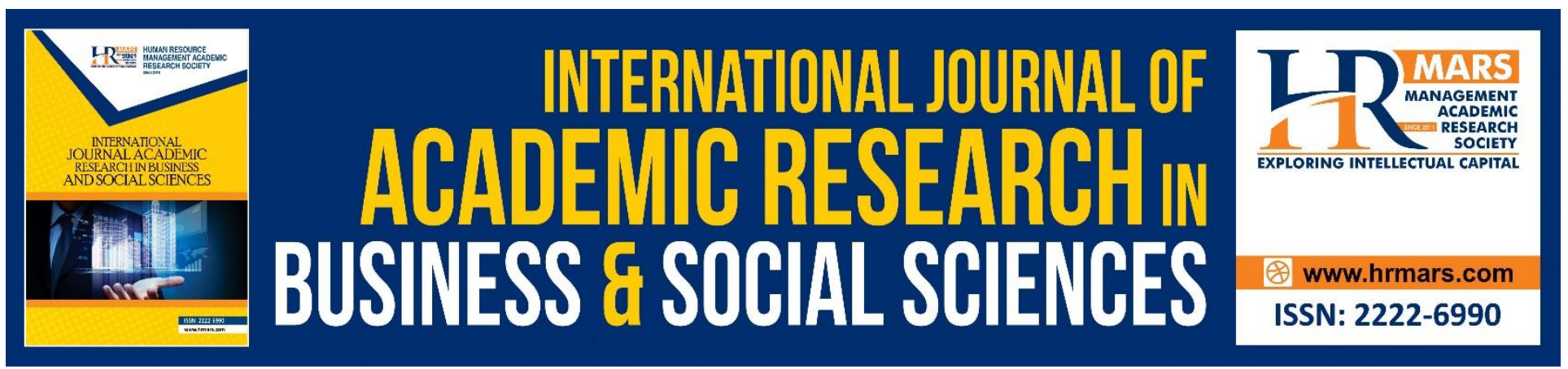

\title{
Impacts of Rewards, Promotions and Supervisor Support on Academic Staff's Performance: An Empirical Study in Malaysian Universities
}

\author{
Safiah Rashid ${ }^{1}$, Mohamed Faroug Ben Hamza², Haliza Mohd Said ${ }^{3}$
}

Faculty of Business and Technology, UNITAR International University, Kelana Jaya, Malaysia

\begin{abstract}
This study was conducted to measure the impacts of rewards, promotions and supervisor support on academic staff's performance in Malaysian universities. A survey method was used in which 166 academic staff were participated. A correlation coefficient and regression analysis were conducted to assess the survey questionnaire data. The result shows that the variables of rewards, promotions and supervisor support have significant positive relationships with the academic staff's job performance.
\end{abstract}

Keywords: Rewards, Promotions, Supervisor Support, Job Performance, Academic Staff, Malaysian Universities

\section{Introduction}

Employees are the most important assets for an organization since they are the key components to propel the organization to achieve goals. Successful organization stem from the effectiveness of job performance of its employees (Kiruja \& Mukuru, 2018; Mone \& London, 2018). If employees have a limited work efficiency, capability, motivation and organization engagement, this leads to some work issues such as non-functional work performance, occurrence of work relocation, and high rate of recruiting new employees. These work issues have negative effect on the organization's success (Kanchanopast, 2013). On the other hand, if the organization has employees who are willing to work, love their jobs, enthusiastic, have positive work attitudes and committed, job performance will result in highest efficiency and effectiveness.

Most organizations attempt to discover and explore factors that affect job performance because job performance is one of the critical elements to the organizational performance. Since 1950's, researchers were trying to discover the purpose of differences in employees' performance that is why they started examining the field of motivation (Saeed et al, 2013). Various effective components on job performance comprises of work environments, the linking and relationship between subordinators' and supervisors, training procedures and development opportunities, 
INTERNATIONAL JOURNAL OF ACADEMIC RESEARCH IN BUSINESS AND SOCIAL SCIENCES Vol. 8, No. 9, Sept. 2018, E-ISSN: 2222-6990 @ 2018 HRMARS

policies of firm rewarding and the job security. The highest level of employee's performance occurs if they find that their effort is fully rewarded. In fact, motivation derived from rewards is considered as a major significant and vital factor among all the active constituents of employees' performance. This concept involves many various procedures that affects worker behavior to succeed certain particular objectives (Baron, 1983).

The links between rewards, promotions, supervisory support and job performance are extremely significant to the success of any organizations (Ndungu, 2017; Owais Khan, 2015; Saharuddin \& Sulaiman, 2016). Rewards management is one of the approaches used by HR managers to attract and maintain suitable employees. It enables the managers to increase the performance by motivation and to conform with employment regulation and instruction. Subsequently, HR managers shall plan for reward programs that enable the organization meets its strategic goals as well as employee's goals. The main purpose of the reward programs is to provide a systematic method that delivers more positive outcome for the organization, which is very critical to organizations (Danish \& Usman, 2010; Maund, 2001; Owais Khan, 2015). Reward programs consist of awards and different forms of recognition, reassignments, non-monetary advantages such as holidays, trips or even a word of thanks (Njanja, et al., 2013). According to Eisenberger (2011) and Heng (2012) if organization failed to reward the workers, that will immediately lead to reduction of employee performance. The effective reward system is for sure a worthy motivator, but an ineffective reward system may cause discourage of the employees in relations of little efficiency and productivity, increase in absenteeism and turnover rate, internal conflicts, absence of commitment and reliability, delay and unfair treatment.

In addition to rewards, promotion systems are seen to play a vital function in determining the job performance. Previous studies have shown that promotion influences employee performance (Saharuddin \& Sulaiman, 2016). Promotions systems allocate employees to the jobs that matching their skills and that will help to move them up rapidly if they are talented employees (Gibbons 1997). The main goals of promotions systems are to give a reward for the employee past efforts, encourage the investments in the human capital and to minimize the turnover rate (Lazear 1998). Seeking for promotion motivates the better workers to retain and participate in the human capital.

Apart from rewards and promotion, supervisor support also plays a substantial role in increasing employee job performance. Numerous studies have concentrated on the relationship between supervisor and employees work outcomes (Douglas, 2012; Fry et al., 2011; Hannah et al., 2008; Jung et al., 2009; Levay, 2010; Mehra et al., 2006; Osborn \& Marion, 2009; Piccolo \& Colquitt, 2006; Zhu et al., 2011). As the first-line managers, supervisors who lead work groups in organizations are responsible on major duties (Elangovan \& Karakowsky, 1999). The literature review of social and organizational support showed that, if the supervisors treated their subordinates' workers in a helpful and supported manner, this will reflect a favorable result on the work performance of the employees it minimizes the job stress among them (Darolia et al., 2010; Oluseyi \& Ayo, 2009; Rhoades \& Eisenberger, 2002). Consequently, organization required to develop tactical human resource programs to keep competent employees achieve desired competitive advantage (Edirisooriya, 2014). Therefore, the purpose of this study is to measure the impacts of rewards, promotions and supervisor support on academic staff's performance in Malaysian universities. 
The contributions of this study are threefold. First, the relationship among rewards, promotions, and supervisor support with job performance were examined. Good employee's performance is an important factor to obtaining organization goals and success. It is likely that rewards, promotions and supervisor relationship would have reflection on their overall performance in the organization. Secondly, this study shall put some lights on the importance of the previously mentioned factors on job performance so that competitive advantages could be attained. The study will also provide further knowledge about the three major factors that positively reflect employee's behavior to be more successful and well performed members. Lastly, with the growth of industrial sectors in Malaysia, a lot of universities academic staffs have decided to quit from their universities job and to move for industry jobs (Malaysian Ministry of Higher Education, 2006). It seems that academic staff have quit their jobs for industries due to reasons such as some are looking for better offer and others move because they seek industrial experiences. Yet, some moved due to academic institution's management inability to achieve the employees' job desire. These reason for leaving might become pricey on the reputation of the academic institution as well as the welfare of the students.

\section{Literature Review}

Vroom (1964) has studied the correlation between job performance and employees' motivation. He found that there is no significant correlation between the variables. According to Vroom (1964) an employee's performance depends on specific personal factors such as character, knowledge, proficiency, experts and capabilities. However, another study carried out by Petty et al., (1984), found that job performance is positively related to the employees' motivation. Job performance is defined as the total estimated value from employees' behaviour carried out over a specific period of time (Motowidlo et al., 1997). Others defined job performance as "the entire employees behavior appointed when they are at work" (Jex, 2002). In addition, the concept of job performance can be categorized into two categories namely task performance and contextual performance (Borman \& Motowidlo, 1993). The two categories of job performance behaviours are considered to be crucial and necessary in organizations. As such, scholars have concentrated their hard work on finding the factors affecting the job performance (Pine \& Dyne, 2001; Van Scotter, 2000).

Futrell in 1975 mentioned that rewards and performance productivity have an impact on the effectiveness and morality of the organization. In depth, the idea clarifies correlation between employees' job performance and reward program. According to Armstrong (2010), reward management is defined as the strategy, policies and procedures essential to guarantee that the value of people and their support for the organization is recognized and rewarded. Hence, to achieve the commitments and goals in business, organizations required to develop reward strategy to make sure that what employees contribute for the organization will have a value (Armstrong, 2010). Although the necessity in rewarding others is relatively understood from a theoretical view (Gohari, Hosseinipour, \& Zohoori, 2013) and previous studies have demonstrated positive relationship between rewards and job performance however further understanding is needed in the context of academic staff in Malaysia. 
INTERNATIONAL JOURNAL OF ACADEMIC RESEARCH IN BUSINESS AND SOCIAL SCIENCES Vol. 8, No. 9, Sept. 2018, E-ISSN: 2222-6990 @ 2018 HRMARS

Promotion program is based on gradually-time requirements, which is usually does not include any duties change or obligation changes. However, it may include higher wages and different designate (Lewis, 1986). Based on the applied definition of promotion, employees obtain the promotion if they moved from their position to a higher level in the same organization. They will have significant change in their obligation and tasks or their duties are carried out in other divisions within the same organization (Russo \& Hassink 2005). Allen, (1997) and Ferris et al., (1992) stated that the promotion system is commonly used in organization. However, only few studies were carried out to find out the effect of job and organization factors on the aspect of promotion system (Ferris et al., 1992; Malik, Danish \& Yasin, 2012) and these studies showed inconclusive result (Allen, 1997).

Supervisor support leads for employees to high commitment through job satisfaction and motivation. Supervisor support is defined as the employees' confidence towards supervisor contributions and attention (Eisenberger et al., 2002). The workers seek for motivation to spend better efforts and extra individual incomes for tasks innovation if their supervisor show their specific and personal attention toward subordinates, such as subordinates will probable receive the friendliness and concern from the supervisors. Likewise, workers who see enough supervisors support frequently feel appreciative to return their supervisors' helps or consideration by assisting them to achieve their planed objectives (Kottke \& Sharafinski 1988, Rui \& Wenquan, 2008, Eisenberger et al., 2002).

The above literature has been used as the platform and foundation to develop a conceptual framework for this study as shown in Figure 1. The study framework included the dependent variable (Job Performance), and independent variables (Rewards, Promotions, and Supervisor support).

Independent Variables

Dependent Variable

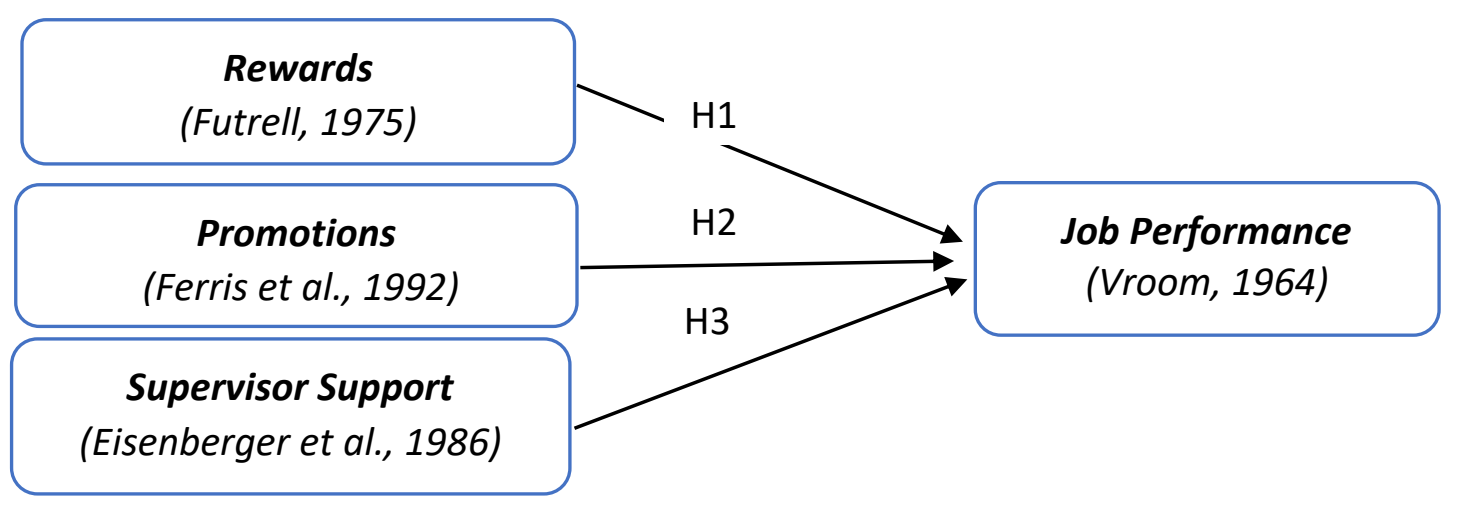

Figure 1. The Theoretical Framework of this study

Based on the above theoretical framework, it can hypothesized that: 
INTERNATIONAL JOURNAL OF ACADEMIC RESEARCH IN BUSINESS AND SOCIAL SCIENCES

Vol. 8, No. 9, Sept. 2018, E-ISSN: 2222-6990 @ 2018 HRMARS

H1: There is a relationship between reward and job performance.

H2: There is a relationship between promotion and job performance.

H3: There is a relationship between supervisor support and job performance.

\section{Methodology}

In this study, the quantitative approach was used. In particular, the research design was a crosssectional. The target population for the study was 200 lecturers from University of Malaya and National University of Malaysia involving those from Faculty of Dentistry, Faculty of Engineering, and Faculty of Education. Sample from each category of lecturers, assistant lecturers and Professors was purposely selected, thus simple random sampling was applied to make sure that all those in the defined population got an equal chance of being selected (Gay, 1996).

The reliability test results are presented in Table 1 and Table 2 are shown below. All independent and dependent variables were reliable since the Cronbach's Alpha more than 0.7.

Table 1. Reliability test among Independent Variables

\begin{tabular}{lll}
\hline Independent variables & Cronbach's Alpha & Number of Item \\
\hline Rewards & .870 & 10 \\
Promotions & .939 & 10 \\
Supervisor Support & .890 & 10 \\
\hline
\end{tabular}

Table 2. Reliability test among Dependent Variable

\begin{tabular}{lll}
\hline Dependent variable & Cronbach's Alpha & Number of Item \\
\hline Job Performance & .920 & 10 \\
\hline
\end{tabular}

The raw data from the questionnaires was quantitatively analyzed using descriptive statistics by statistical package for social science (SPSS). The regression analysis was used to indicate whether two variables are associated.

\section{Results and Discussion}

The main objective of this study was to investigate the impacts of rewards, promotions, and supervisor support on academic staff's performance in Malaysian universities. Most of the respondents were males (54.2\%), married (57.2\%) and within the age bracket of 35-43 (52.4\%) of the total sample. In term of academic qualification, majority of respondents was postgraduate academic staff (81.9\%).

In this study, multiple regression analysis technique was conducted to examine the hypotheses for the study. The results in Table 3 indicated that, $77.5 \%$ of variance was explained by these three variables $\left(R^{2}=.775\right)$. 
Table 3. Model Summary

\begin{tabular}{|l|l|l|l|l|}
\hline Model & $R$ & R Square & $\begin{array}{l}\text { Adjusted R } \\
\text { Square }\end{array}$ & $\begin{array}{l}\text { Std. Error of } \\
\text { the Estimate }\end{array}$ \\
\hline 1 & $.880^{\mathrm{a}}$ & .775 & .771 & .37901 \\
\hline
\end{tabular}

a. Predictors: (Constant), Supervisor, Rewards, Promotion

b. Dependent Variable: Job Performance

Furthermore, the substantial " $F$ " statistic of 186.152 and significance of .000 (Table 4) lead us to be confident that there is a very strong relationship between the independent variables (Reward practice, Promotion program, Supervisor support) and the dependent variables (job performance) among the academic lecturer in public and private universities in Malaysia.

\section{Table 4. ANOVA}

\begin{tabular}{|ll|l|l|l|l|l|}
\hline \multicolumn{2}{|l|}{ Model } & $\begin{array}{l}\text { Sum of } \\
\text { Squares }\end{array}$ & df & $\begin{array}{l}\text { Mean } \\
\text { Square }\end{array}$ & F & Sig. \\
\hline \multirow{4}{*}{1} & Regression & 80.222 & 3 & 26.741 & 186.152 & $.000^{\mathrm{b}}$ \\
& Residual & 23.271 & 162 & .144 & & \\
& Total & 103.493 & 165 & & & \\
\hline
\end{tabular}

a. Dependent Variable: Job Performance

b. Predictors: (Constant), Supervisor, Rewards, Promotion

Based on the coefficient analysis (Table 5), it can be concluded that Reward practice, promotion program, and Supervisor support play a significant role in job performance among the academic lecturer working in public and privet universities in Malaysia. From the findings, it seems that the highest beta coefficient was obtained by the factor promotion program (0.524) followed by supervisor support (0.377) and the lowest were for the factor rewards (0.032) when Job Performance is predicted for.

\section{Table 5: Coefficients}

\begin{tabular}{|c|c|c|c|c|c|c|c|}
\hline \multirow[t]{2}{*}{ Model } & \multicolumn{2}{|c|}{ Unstandardized Coefficients } & Standardized Coefficients & \multirow[t]{2}{*}{$\mathrm{t}$} & \multirow[t]{2}{*}{ Sig. } & \multicolumn{2}{|c|}{ 95.0\% Confidence Interval for B } \\
\hline & $B$ & Std. Error & Beta & & & Lower Bound & Upper Bound \\
\hline (Constant) & .375 & .147 & & 2.544 & .012 & .084 & .665 \\
\hline Rewards & -.032 & .063 & -.033 & -.507 & .613 & -.157 & .093 \\
\hline${ }^{\perp}$ Promotion & .524 & .065 & .600 & 8.004 & .000 & .395 & .653 \\
\hline Supervisor & .377 & .072 & .348 & 5.209 & .000 & .234 & .520 \\
\hline
\end{tabular}

a. Dependent Variable: Job Performance 
A linear test was used to examine whether the positive relationship was present between Rewards and Job Performance. As shown in the Table 6 and Table 7 the value R. Squared is 49\% ( $R=$ $0.497)$ this is supported by Beta values of $70 \%(B=0.705)$. Moreover, the $p$ value of 0.007 shows statistical significance between rewards and job performance. Thus, the alternate hypothesis can be accepted which states that there would be positive significant relationship between the universities' rewards programs and the academic staff's job performance. The finding supports past findings where the authors noted that reward management have an impact on the organization job performance (e.g. Futrell, 1975; Yang, 2008; Yazici 2008).

Table 6. Model Summary

\begin{tabular}{llllll}
\hline Model & $\mathbf{R}$ & R Square & $\begin{array}{l}\text { Adjusted } \\
\text { Square }\end{array}$ & $\begin{array}{l}\text { R Std. Error of } \\
\text { the Estimate }\end{array}$ \\
\hline $\mathbf{1}$ & $.705^{\mathrm{a}}$ & .497 & .494 & .56319 \\
\hline
\end{tabular}

Table: 7. Coefficient of independent variable (Rewards)

\begin{tabular}{l|l|l|l|l|l}
\hline Model & \multicolumn{2}{|l|}{$\begin{array}{l}\text { Unstandardized } \\
\text { Coefficients }\end{array}$} & $\begin{array}{l}\text { Standardized } \\
\text { Coefficients }\end{array}$ & $\mathbf{T}$ & Sig. \\
\hline & B & $\begin{array}{l}\text { Std. } \\
\text { Error }\end{array}$ & Beta & & \\
\hline $\begin{array}{l}\text { (Constant) } \\
\text { Rewards }\end{array}$ & .518 & .188 & .705 & 2.750 & .007 \\
\hline
\end{tabular}

Similarly, to conclude whether there is positive relationship was present between Promotion and Job Performance, a linear test was applied. As shown in the Table 8 and Table 9 the value R. Squared is $73 \%(R=0.737)$ this is supported by Beta values of $85 \%(B=0.858)$. Moreover, the $p$ value of 0.000 shows statistical significance between rewards and job performance. Therefore, $\mathrm{H} 2$ is also accepted. Past studies also supported the finding where the authors agreed that the promotion program has a positive impact on employees' job performance (Ferris et al., 1992; Lazear 1992; McCue 1992; Medoff \& Abraham 1980). 
INTERNATIONAL JOURNAL OF ACADEMIC RESEARCH IN BUSINESS AND SOCIAL SCIENCES

Vol. 8, No. 9, Sept. 2018, E-ISSN: 2222-6990 @ 2018 HRMARS

Table 8: Model Summary

\begin{tabular}{llllll}
\hline Model & $\mathbf{R}$ & R Square & $\begin{array}{l}\text { Adjusted } \\
\text { Square }\end{array}$ & $\begin{array}{l}\text { Std. Error of } \\
\text { the Estimate }\end{array}$ \\
\hline $\mathbf{1}$ & $.858^{\mathrm{a}}$ & .737 & .735 & .40774 \\
\hline
\end{tabular}

Table 9. Coefficient of independent variable (Promotions)

\begin{tabular}{l|l|l|l|l|l}
\hline Model & \multicolumn{2}{|l|}{$\begin{array}{l}\text { Unstandardized } \\
\text { Coefficients }\end{array}$} & $\begin{array}{l}\text { Standardized } \\
\text { Coefficients }\end{array}$ & $\mathbf{t}$ & Sig. \\
\hline & $\mathrm{B}$ & $\begin{array}{l}\text { Std. } \\
\text { Error }\end{array}$ & Beta & & \\
\hline (Constant) & .825 & .100 & .858 & 8.262 & .000 \\
\hline Promotion & .750 & .035 & & 21.413 & .000 \\
\hline
\end{tabular}

Likewise, to determine whether there is a positive relationship present between Supervisor Support and Job Performance, a linear test was conducted. As shown in the Table 10 and Table 11 the value $R$. Squared is $66 \%(R=0.663)$ this is supported by Beta values of $81 \%(B=0.814)$. Moreover, the $p$ value of 0.000 shows statistical significance between rewards and job performance. Thus, we accept the alternate hypothesis that there is a positive relationship between the supervisor support and the job performance. Our study finding is similar to previous studies which noted that the supervisor support among an organization staff will increase their job performance (Eisenberger et al., 1986; Jung et al., 2003; Shalley \& Gilson, 2004; Janssen 2003).

Table 10. Model Summary

\begin{tabular}{lllll}
\hline Model & $\mathbf{R}$ & R Square & $\begin{array}{l}\text { Adjusted } \\
\text { Square }\end{array}$ & $\begin{array}{l}\text { Std. Error of } \\
\text { the Estimate }\end{array}$ \\
\hline $\mathbf{1}$ & $.814^{\mathrm{a}}$ & .663 & .661 & .46116 \\
\hline
\end{tabular}

Table 11. Coefficient of independent variable (Supervisor Support)

\begin{tabular}{l|l|l|l|l|l}
\hline Model & \multicolumn{2}{|l|}{$\begin{array}{l}\text { Unstandardized } \\
\text { Coefficients }\end{array}$} & $\begin{array}{l}\text { Standardized } \\
\text { Coefficients }\end{array}$ & $\mathbf{t}$ & Sig. \\
\hline & $\mathrm{B}$ & $\begin{array}{l}\text { Std. } \\
\text { Error }\end{array}$ & Beta & & \\
\hline (Constant) & .118 & .156 & .814 & .753 & .452 \\
\hline Supervisor & .882 & .049 & & 17.962 & .000 \\
\hline
\end{tabular}


INTERNATIONAL JOURNAL OF ACADEMIC RESEARCH IN BUSINESS AND SOCIAL SCIENCES Vol. 8, No. 9, Sept. 2018, E-ISSN: 2222-6990 @ 2018 HRMARS

In conclusion, results showed a significant and positive relationship between all independent variables (rewards, promotion, and supervisor support) and job performance, with the highest impact being from promotion followed by the supervisor support, and the lowest was from rewards. Table 12 depicted below shows the results of the hypotheses testing.

Table 12. Results of hypothesis testing

\begin{tabular}{l|l}
\hline Hypothesis & Remarks \\
\hline H1: There is a relationship between Rewards and Job Performance & Accepted \\
H2: There is a relationship between Promotions and Job Performance & Accepted \\
\hline $\begin{array}{l}\text { H3: There is a relationship between Supervisor Support and Job } \\
\text { Performance }\end{array}$ & Accepted \\
\hline
\end{tabular}

\section{Conclusions and Recommendations}

The findings of this study demonstrate that all three independent variables namely rewards, promotions and supervisor support have significant positive correlation with job performance (dependent variable) of academic staff.

The relationship between rewards and job performance among lecturers in Malaysian universities is supported with Beta value of $70 \%$. This implies that those who received and underwent any sort of reward system showed an increased job performance. This finding has been supported by Barber and Bretz (2000) who found that reward management systems have main influence on organizations ability to catch, hold and motivate high potential employees as a result getting the great levels of task performance with better skills and increased job performance. The relationship between promotion programs and job performance among lecturers in Malaysian universities. indicated a significant positive correlation (Beta value $85 \%$ ). Findings are supported by Jacoby (1984) and Morishima (1986) who pointed out that promotion chances raise the level of personal performance. Obviously thus, according to the respondents' opinions about promotion, it is apparent that academic promotions are affecting on lectures individual performance. Preponderance of the respondents stated that for the better performance they show, the greater promotion chances they obtain and vice versa.

Finally, the relationship between supervisor support and job performance among academic staff in Malaysian universities also indicate a significant positive correlation (Beta value $81 \%$ ). Eisenberger et al, (2002) stated that employees who perceive supervisors support are often feel obligated to return supervisors' kindness by assisting supervisors to reach their stated objectives. Moreover, Janssen (2003) observed that workers reacted more creatively to greater levels of job demands if they perceived that their hard work will properly reward from the supervisors.

With reference to the findings, management team should create a year plan strategy about career development for all academic staff to ensure that all academics are given fair opportunity by 
INTERNATIONAL JOURNAL OF ACADEMIC RESEARCH IN BUSINESS AND SOCIAL SCIENCES

Vol. 8, No. 9, Sept. 2018, E-ISSN: 2222-6990 (C) 2018 HRMARS

designing specific criteria and administering these criteria appropriately. Guidelines and opportunities on career development should be communicated to all academic staff through circular/memos and meetings that guarantee all academic staff are well informed.

Lastly when developing or reviewing the goals and aims of the organization, the involvement of the academic staff should become a priority, so that their ideas can form part of the development process, thus allowing successful implementation. Management is advised to confirm that existing benefits for academic staff are equally, fairly and competitively allocated to them.

\section{Acknowledgement}

We thank the anonymous referees for their useful suggestions and those who have participated in this study both directly and indirectly.

\section{Corresponding Author}

Safiah Rashid

Faculty of Business and Technology, UNITAR International University

Malaysia

Email: safiah@unitar.my

Level 2, Tierra Crest

3-01A, Jalan SS6/3, Kelana Jaya, 47301, Petaling Jaya, Selangor, Malaysia

\section{References}

Allen, G. (1997). Antecedents and outcomes of promotion systems. Human Resource Management, 36(2), 251-259.

Armstrong, M. (2010). Armstrong's essential human resource management practice. London: Kogan Page.

Barber, A.E. \& Bretz, R.D. Jr. (2000). Compensation, attraction, and retention. In Rynes, S.L. \& Gerhart, B. (Eds). Compensation in organization, (pp.32-60). Jossey-Bass, San Francisco, CA.

Baron, R.A. (1983). Behaviour in organizations. New York: Allyn \& Bacon, Inc.

Borman, W., \& Motowidlo, S. (1993). Expanding the criterion domain to include elements of contextual performance. In N. Schmitt \& W.

Darolia, C. R., Kumari, P., \& Darolia, S. (2010). Perceived organizational support, work motivation, and organizationalcCommitment as determinants of job performance. Journal of the Indian Academy of Applied Psychology, 36(1), 69-78.

Douglas, C. (2012). The moderating role of leader and follower sex in dyads on the leadership behavior leader effectiveness relationships. The Leadership Quarterly,23, 163-175. 
INTERNATIONAL JOURNAL OF ACADEMIC RESEARCH IN BUSINESS AND SOCIAL SCIENCES Vol. 8, No. 9, Sept. 2018, E-ISSN: 2222-6990 (C) 2018 HRMARS

Danish, R. Q. \& Usman, A. (2010). Impact of reward and recognition on job satisfaction and motivation: An empirical study from Pakistan. International Journal of Business and Management, 5(2), $159-167$.

Edirisooriya, W. A. (2014). Impact of rewards on employee performance: With special reference to ElectriCo. International Conference on Management and Economics, 311-318.

Elangovan, A. R., \& Karakowsky, L. (1999). The role of trainee and environmental factors in transfer of training: An exploratory framework. Leadership and Organization Development Journal, 20(5). 268-276.

Eisenberger, R., \& Stinglhamber, F. (2011). Perceived organizational support: Fostering enthusiastic and productive employees. Washington, DC: APA.

Eisenberger, R., Stinglhamber, F., Vandenberghe, C., Sucharski, I. L., \& Rhoades, L. (2002). Perceived supervisor support: Contributions to perceived organizational support and employee retention. Journal of Applied Psychology, 87, 565-573.

Eisenberger R., Huntington R., Hutchison S., \& Sowa D., (1986). Perceived organizational support. Journal of Applied Psychology, 71, 500.

Ferris, G.R., M.R. Buckley \& G.M. Allen. (1992). Promotion systems in organizations. Human Resource Planning, 15, 47-68.

Fry, L.W., Hannah, S.T., Noel, M., \& Walumbwa, F.R. (2011). Impact of spiritual leadership on unit performance. The Leadership Quarterly, 22, 259-270.

Futrell, C.M., (1975). Salesman's reward systems: A Comparative approach. Journal of academy of marketing science, 4, 328- 346.

Gay, L. R. (1996). Educational research: Competencies for analysis and application (4th ed.). Beverly Hills, CA: SAGE.

Gibbons, R (1997). Incentives and careers in organizations, advances in economics and econometrics: Theory and applications, Vol. II.

Gohari, P., Kamkar, A., Jafar, S., Hosseinipour, Zohoori, M., (2013). Relationship between rewards \& employee performance: A mediating role of job satisfaction. Interdisciplinary Journal of Contemporary Research in Business, 5(3). 
INTERNATIONAL JOURNAL OF ACADEMIC RESEARCH IN BUSINESS AND SOCIAL SCIENCES

Vol. 8, No. 9, Sept. 2018, E-ISSN: 2222-6990 (C) 2018 HRMARS

Hannah, S.T., Avolio, B.J., Luthans, F., \& Harms, P.D. (2008). Leadership efficacy: Review and future directions. The Leadership Quarterly, 19, 669-692.

Jacoby, S.M. (1984). Employing bureaucracy: Managers, unions and the transformation of work in American industry (1990-1945). New York: Columbia University Press.

Janssen, O. (2003). Innovative behaviour and job involvement at the price of conflict and less satisfactory relations with co-workers. Journal of Organizational and Occupational Psychology, 76, 347-364.

Jex, S.M. (2002). Organizational psychology: A scientist-practitioner approach. John Wiley \& Sons, New York.

Jung, D., Yammarino, F.J., \& Lee, J.K. (2009). Moderating role of subordinates' attitudes on transformational leadership and effectiveness: A multi-cultural and multi-level perspective. The Leadership Quarterly, 20, 586-603.

Jung, D. I., Chow, C., \& Wu, A. (2003). The role of transformational leadership in enhancing organizational innovation: Hypotheses and some preliminary findings. The Leadership Quarterly, $14,535-544$.

Kanchanopast, S. (2014). The factors influencing successful implementation of E-Commerce within SMEs Businesses. International Journal of Social, Behavioral, Educational, Economic, Business and Industrial Engineering, 8. doi:1999.10/9999679

Kiruja, E. K. \& Mukuru, E. (2018). Effect of motivation on employee performance in public middle level technical training institutions in Kenya. International Journal of Advances in Management and Economics, 2(4), $73-82$.

Kottke, J.L., \& Sharafinski, C.E. (1988). Measuring perceived supervisory and organizational support. Educational and Psychological Measurement, 48, 1075-1079.

Lazear, E. (1998), Personnel economics for managers. New York: John Wiley \& Sons Mary Jane (n.d). Employee Promotion \& Performance Appraisal, eHow. Retrieved August 08, 2012 from http : // www.ehow.com / info 7864603 employee-promotion-performance appraisal.html.

Lazear, E.P. (1992). The job as a concept. In W.J. Bruns (Ed.), Performance Measurement, Evaluation, and Incentives. Harvard Business School Press, Boston, MA, pp. 183-215.

Lewis, Gregory B. (1986). Race, sex, and supervisory authority in Federal white-collar employment. Public Administration Review, 46 (1), 25-30. 
INTERNATIONAL JOURNAL OF ACADEMIC RESEARCH IN BUSINESS AND SOCIAL SCIENCES

Vol. 8, No. 9, Sept. 2018, E-ISSN: 2222-6990 (C) 2018 HRMARS

Levay, C. (2010). Charismatic leadership in resistance to change. The Leadership Quarterly, 21, 127143

Malik, M.E., Danish, R. Q., \& Yasin, M. (2012). The role of transformational leadership and leader's emotional quotient in organizational learning, World Applied Sciences Journal 16, (6), 814-818.

Maund, L. (2001) An introduction to human resource management: Theory and practice. New York: Palgrave.

McCue, K. (1992). Job mobility within the firm. Department of Economics, Texas A\&M, 1992.

Medoff, J. \& Katherine, A. (1980). Experience, performance, and earnings. Quarterly Journal of Economics 95(4) : 703-36.

Mehra, A., Smith, B.R., Dixon, A.L. \& Robertson, B. (2006). Distributed leadership in teams: The network oflLeadership perceptions and team performance. The Leadership Quarterly,17, 232245.

Mone, E.M. \& London, M. (2018). Employee engagement through effective performance management. A practical guide for managers ( $2^{\text {nd }}$ ed.) New York: Routledge.

Morishima, M. (1986). Evolution of white-collar human resource management in Japan. In Lewin D. Kauffman, B.E.\& Soucell D. (eds). Advances in industrial and labour relations. JAI Press Greenwich CT. Vol 7 (pp. 146-76).

Motowidlo, S., Borman, W., \& Schmidt, N. (1997). A theory of individual differences in task and contextual performance. Human Performance, 10, 71-83.

Ndungu, D.N. (2017). The effects of rewards and recognition on employee performance in public education institutions: A Case of Kenyatta University, Kenya. Global Journal of Management and Business Research: A Administration and Management, 17(1).

Njanja, W., Maina, R., \& Njagi, K. (2013). Effect of reward on employee performance: A case of Kenya Power and Lighting Company Ltd, Nakuru, Kenya. International Journal of Business and Management, 8 (21), 41-49.

Oluseyi, A.S. \& Ayo H, (2009). Influence of work motivation, leadership effectiveness and time management on employees' performance in some selected industries in Ibadan, Oyo State Nigeria European Journal of Economics, Finance and Administrative Sciences, 16 (2009), 717. 
INTERNATIONAL JOURNAL OF ACADEMIC RESEARCH IN BUSINESS AND SOCIAL SCIENCES

Vol. 8, No. 9, Sept. 2018, E-ISSN: 2222-6990 (C) 2018 HRMARS

Osborn, R.N., \& Marion, M. (2009). Contextual leadership, transformational leadership and the performance of international innovation seeking alliances. The Leadership Quarterly, 20, 191206.

Owais Khan, M.I. (2015). The impact of reward on employee performance (A case study of Malakand Private School). International Letters of Social and Humanistic Sciences, 52, 95-103.

Petty, M, M., McGee, G, M., \& Cavender, J. W. (1984). A meta- analysis of the relationships between individual job satisfaction and individual performance. Academy of management Review, 9, 712721.

Piccolo, R. \& Colquitt, J. (2006) 'Transformational leadership and job behaviours: The mediating role of core job characteristics. Academy of Management Journal, 49(2): 327-340.

LePine, JA \& L Van Dyne (1998). Predicting voice behavior in work groups. Journal of Applied Psychology, 83(6), 853-868.

Rui Li, W.L. (2008). A Review of the researches on transformational leadership", Soft Science, vol.22, no.2, pp.70-73,78.

Russo, G. \& Hassink, W. H. J. (2005). The part-time wage penalty: A career perspective, IZA Discussion Paper, No 1468

Rhoades, L., \& Eisenberger, R. 2002. Perceived organizational support: A review of the literature. Journal of Applied Psychology, 87: 698-714.

Saeed, R., Mussawar, S., Lodhi, R. N., Iqbal, A., Nayab, H. H., \& Yaseen, S. (2013). Factors affecting the performance of employees in Telecom sector of Pakistan. Middle-East Journal of Scientific Research, 16(11), 1476-1482

Saharuddin \& Sulaiman. (2016). The effect of promotion and compensation toward working productivity through job satisfaction and working motivation of employees in the department of water and mineral resources energy, North Aceh District. International Journal of Business and Management Invention, 5(10), 33-40.

Shalley, C.E., \& Gilson, L.L. (2004). What leaders need to know: A review of social and contextual factors that can foster or hinder creativity. The Leadership Quarterly, 15, 33-53.

Van Scotter, J., Motowidlo, S. J., \& Cross, T. C. (2000). Effects of task performance and contextual performance on systemic rewards. Journal of Applied Psychology, 85, 526-535.

Vroom, V. H. 1964. Work motivation. New York: John Wiley and Sons. 
INTERNATIONAL JOURNAL OF ACADEMIC RESEARCH IN BUSINESS AND SOCIAL SCIENCES

Vol. 8, No. 9, Sept. 2018, E-ISSN: 2222-6990 (C) 2018 HRMARS

Yang, H. (2008). Efficiency wages and subjective performance pay. Journal of Economic inquiry, 46, 179-196.

Yazıcı, N.K., (2008). The effect of reward system applications on employee performance in service sector, Master thesis. Marmara University, Institute of social sciences.

Zhu, W., Avolio, B.J., Riggio, R.E., \& Sosik, J.J. (2011). The effect of authentic transformational leadership on follower and group ethics. The Leadership Quarterly, 22, 801-817. 